\title{
- АНТРОПОЛОГІЧНИЙ ПОВОРОТ ЯК ФЕНОМЕН РЕФЛЕКСІЇ У МОДІ XX-XXІ СТОЛІТЬ
}

\section{- Барна Наталія Віталіївна}

- Доктор фрілософрських наук, профресор,

ORCID: 0000-0002-5176-0136, e-mail: barna2005@ukr.net,

Відкритий міжнародний університет розвитку людини «Україна», вул. Львівська, 23, Київ, Україна, 03115

\section{- Для цитування:}

Барна, Н.В. (2019). Антропологічний поворот як феномен рефлексії у моді XX-XXI століть. Питання культурологіï, (35), 11-20. doi: https://doi.org/10.31866/2410-1311.35.2019.188780.

\section{- Анотація}

Мета статті - визначити соціокультурні детермінанти формування систем інтерпретації модної діяльності як фрактора гармонізації глобалізаційних проблем сучасності. У дослідженні використано компаративний та системний підходи, що допомогло визначити моду як систему змін та інновацій у контексті антропологічної проблематики. Такі фрілософські методи, як трансцендентальний, допомагають з'ясувати, наскільки можливі зміни модних інновацій за доби глобалізації; яким чином стають наявними самі зміни (феноменологічний метод); як один цикл модних інновацій перетворюється на інший. Метод культурно-історичної реконструкції допомагає визначити модні артефакти як феномен новітньої культури. Наукова новизна. Антропологічний поворот концентрує увагу на антропному вимірі моди, який свідчить про антропологічну обумовленість модного теоцентризму та теріоморфізму. Висновки. Доведено, що в теорії сучасної естетичної думки, мистецтвознавстві, культурології визначають три повороти: антропологічний, семіотичний та візуальний. Так сталося, що ці повороти розводять у часові, і вважається, що антропологічний передував семіотичному. Проблема дискурсу, тексту, знаку трансформує проблему людини, яка була гостро позначена на межі XIX-XX століть, у площину мовних адеквацій. Антропологічний поворот відображує сьогоднішню ситуацію, яка презентує надмірну, більше того, надзвичайно екстравагантну реальність візуалізації світу, новий оптикум, паноптичний універсум, який дає можливість масмедіа, рекламі, віртуальній реальності демонструвати, презентувати, розширювати світ інформації настільки, що людина майже весь час перебуває у поліваріантному просторі багатовимірного світу екрана. Екран стає настільки дійовим і активним, що фактично усуває проблеми тілесності та ідентичності як онтологічного предикату. В контексті статті визначаються онтологічні трансформації в моді XX століття крізь призму культурних практик сьогодення.

Ключові слова: культура; мода; антропологічний поворот; семіотика; візуальний світ моди 


\section{- Вступ}

Антропологічний, семіотичний та візуальний повороти презентують різні засоби герменевтики та інтерпретації культури. Проте така хронологічна поетапність здається некоректною. Означені повороти, описані в рамках XX століття, не є лише реальністю цього століття, існували від віку як потреба знайти новий ґрунт, метафізичні витоки для культурної дескрипції того чи іншого френомену, зокрема моди в її комунікативному вимірі. Так, антропологічний модус, знаковий і оптичний образ людини презентують саму потребу опису, презентації та модельної інтерпретації як певних поворотів. Корелятивна співмірність знакового, образного і візуального світів так чи інакше виходить на проблеми іміджу, сценічної реальності як онтологію комунікації в моді.

Проблема онтологічних, антропологічних констант як певних поворотів досліджувалася в роботах Н. Барної (2015), де описується наскрізний аналіз антропологічних констант у проектній діяльності, зокрема в дизайні одягу. Феноменологічні та психологічні ознаки проектування визначаються як антропні виміри, проте спеціального антропологічного аналізу не проводиться.

Ю. Легенький (2003) переважно орієнтує свої дослідження на полісистемний аналіз, визначаються антропологічні межі моди як риторична та семіологічна структури. Автор пише про теоморфізм, теріоморфізм моди як певну системну цілісність. В. Савчук (2013) взагалі відмічає, що у XX столітті слід говорити про онтологічний, а не антропологічний поворот, про лінгвістичний та візуальний повороти. Такий підхід проблематизує антропний принцип як сучасну парадигму культуротворення. А. Усманова (2007) аналізує візуальний поворот як переважно соціологічну рефрлексію. Втім варто відмітити, що всі означені повороти виникли не у XX столітті, а існували в режимі синхронії та діахронії, починаючи з давніх культур.

Констатуючи значимість вказаних досліджень, маємо зауважити, що залишаються мало визначеними естетичні та культурологічні аспекти формування культурних матриць інтерпретації моди як антропного феномену.

Завданням статті $є$ здійснити реконструкцію антропологічного, лінгвістичного та візуального поворотів як антропної цілісності в світовій культурі, зокрема в просторі модних інновацій.

\section{Мета статті}

Визначити соціокультурні детермінанти формування систем інтерпретації модної діяльності як фактора гармонізації глобалізаційних проблем сучасності.

У дослідження використано компаративний та системний підходи, що допомогло визначити моду як систему змін та інновацій у контексті антропологічної проблематики. Такі фрілософські методи, як трансцендентальний, допомагають з'ясувати, наскільки можливі зміни модних інновацій за доби глобалізації; яким чином стають наявними самі зміни (феноменологічний метод); як один цикл модних інновацій перетворюється на інший. Метод культурно-історичної реконструкції допомагає визначити модні артефакти як френомен новітньої культури. 


\section{- Виклад матеріалу дослідження}

Варто говорити про діахронію та синхронію антропологічного, семіологічного та візуального поворотів. Якщо заглибитись в історію, то можна в культурологічному вимірі звернутися до творчості Ф. Шміта (Шмитъ, 1919), який розглядав культурологічні цикли розвитку мистецтв, які він визначав як стилі. Втім стильова динаміка в культуротворчому процесі дає можливість більш коректно описати корелятивні стосунки взаємодії антропологічного, знакового і візуального образів як складових переутворень практик культури, зокрема моди. Ми не будемо їх називати «поворотами», бо вони неодноразово «оберталися», на кожному етапі культурного розвитку виникали нові повороти.

Це призводить до певного інваріанта обертання, а фрактично презентується циклізм, ідеативний комплекс як певний ритуалізм відмінювання предметних, візуальних, вербальних настанов або предикацій сутності культури. Ідеться про те, що у верхньому палеоліті той образ світу, який можна зазначити як паннатуралістичний за домінантою візуальності, буквально нейтралізувався і ще не визначався як ідеальний, був тотально цінним і тотально онтологічним.

Фактично така ж ситуація існувала і в Давньому Єгипті, давніх цивілізаціях, де хліб як ієрогліф, знак, хліб намальований і хліб реальний, покладений у сховище фараона, був єдиносущним. Ця єдиносущність, співмірність, спів'єдність усіх артефрактів культури як універсум присутнього світу $є$ синкретичним комплексом. Реальність ще не розділяється на реальність «тут» $\mathrm{i}$ «там». Можна говорити про тотальний міф, тотальність та тоталогію міфотворчості. Якщо ми говоримо про диференційні практики культури, то можемо визначати синкретизми в моді, письмі, архітектурі, адже в них вже існує той зародок унікального самостояння людини в світі, який виходить за межі міфу, структурує реальність присутності людини в образі, знаку, слові, яка потім стає диференційованою.

Виникла диференційна онтологія, а як наслідок - конфлікт онтологій. Так, можливість існування загально сутнього в окремій частині була завжди співмірною культурі як людиновимірному феномену. Абсолют, ідеал, образ як маркери цілісності культури не можна фрагментувати, десакралізувати, рознести по означуваним культурним вимірам.

Отже, вже верхній палеоліт презентував предметну надцінність світу за візуальною домінантою, характеризував взаємини людини і світу, людини і природи. Протокультурний синкретизм згодом розгортається як цивілізаційний спосіб розвитку практик культури, диференціація культурних практик. Отже, перша сцена, перший сценічний простір великого театру модусів світобудування, моди в її планетарному вимірі формується у верхньому палеоліті. Теріоморфрізм (тваринний код) як засада міфологічного тотемізму породжує перші сакральні образи світу. Так, теріоморфізм у моді (одязі, дизайні, архітектурі) імпліцитно існує як настанова фрормотворення.

Якщо коротко описати «повороти» в культуроґенезі за Ф. Шмітом (Шмитъ, 1919), то візуальний у палеоліті змінився семіотичним у неоліті (натуралізм зображення зникає, замінюється графремами-символами), фрормується візуальна символіка давніх цивілізацій (Єгипет, Месопотамія, Іран, Китай, Японія, Латинська Америка), домінує угрупування морфем-символів. Графооматичний 
комплекс змінюється на давньогрецький пластицизм, що акцентує знакову систему ейдосу (виникнення літерного письма заперечує піктографрічне та логографічне письмо). Культура Середньовіччя трансформує пластицизм та семіоз Давньої Греції, адже в добу Відродження вони повертаються. Новий і Новітній час акцентують просторові та часові цінності. Мода відповідно реалізує ці стратегії як антропний код.

Фактично парадигма «повороту» як пошуку метафізичних витоків сутнього була завдана в неоліті. Неолітичний семіоз - вплив знаків - визначається графемами: коло, частини кола, хвилясті лінії ототожнюються з Абсолютом богинею неба, її символізують у вигляді точок, презентують нескінченний вимір життя, який формується як запис, очікування дива, більше того, наднатурального символічного світу. Однак ця позанатуральність і позачутливість має передумову надчуття, тобто великого чуття, чуття єдності з Абсолютом, єдності людини і Великої богині, яка забирала і породжувала людей. I зараз у моді до нас доходять відзнаки абсолюту: обручка, яка одягається при одруженні, вінки, що приносяться на могилу, намисто тощо. Взагалі всі підв'язки характеризують семантику неба, перетину світового тіла, що характеризує той семіоз, який символічно відображує спільність людини і світу.

Образи-символи неба і землі, їх первинний шлюб стають моделюючим образом єдності предметного світу в одязі. Отже, денотат (символічно означений предмет моди), що презентує собою надцінність буття, не має буквального визначення в зображенні, слові, зберігається як певний оберіг цілісності людини і світу. Фактично ми потрапляємо в «протоавангард», який свідчить про те, що надреальність не може бути натурально окресленою і сформована як тип поведінки, діяльності, стану. Антропологічний модус моди є вже явно визначеним.

Метафрізична колиска людства - небо. Небо - мати всього сутнього. Образи неба назавжди залишились у міфі. Втім первинний фемінізм, як і матріархат, трансформуються. Чоловічий виток усуває жіночий. Симбіоз формотворчих настанов фемінного та маскулінного стає вибуховим, якщо не сказати - катастрофічним. I взагалі андрогінність, «гібридність» гендерних витоків моди, як би це метафорично не звучало після гібридних війн, після селекції Мічуріна, онтичного демаршу проти традиційної метафізики та онтології Гайдеггера, який провів селекцію онтологічного простору, заснувавши фундаментальну онтологію, свідчать про онтологічні предикації суто антропного типу. Все свідчить про те, що вже в давніх культурах можна побачити весь комплекс проблем, який зараз намагаються визначити як реалії XX-XXI століть, забуваючи про те, що еквівокація (двоосмисленість) - ми використовуємо термінологію середньовічної філософії - $є$ двоосмисленням реальності під кутом зору лінгвістики, семіотики, антропології, де полівалентність, амбівалентність, протиріччя, протиставлення як фрігури діалектичного мислення фрормувались і як певне сперечання реалій, сперечання інтерпретацій бачення сутнього.

Мода завжди залишається цілісною, синкретичною, синтетичною як образна цілісність. Так, вже мода Давньої Греції доводить, що завданий лад, порядок, стрій, космос формуються як певне ідеальне тіло - фрлеш-імідж. Під космосом розуміємо тіло, образ, розумний вид, тобто має певний алгоритм, 
який використовує пропорційну складову. На поверхню філософрської рефлексії виносяться логос, розум як певна логографія, що має завершену канонічну автентику. Логографрія моди - це той синтетичний конструкт вестіментарного коду, який опанував Р. Барт (2003) у 60-ті роки XX століття. Йдеться про те, що образ людини в моді стає залежним від індустрії, реклами, риторичного дискурсу модних (глянцевих) журналів тощо. Знову виникає потреба звернення до ідеальної тілесності людини всесвіту (платонових тіл), замкнених, завершених форм, самодостатніх аналогів антропологічного виміру світу. Все це свідчить про те, що ми маємо амбівалентну структуру єдності слова, зображення, предметного світу моди як завершеного цілого вже в контексті постструктуралістської рефлексії.

Отже, антропологічний поворот не може бути радикально першим як поштовх до семіотичного та візуального повороту. В XX столітті теж не можна хронологічно його позначити як породжуючий виток, з якого виникли всі інші моделі розшуку, нового витоку культуротворення (семіотична та візуальна моделі). Людина є верхівкою Божого творіння, за середньовічними прописами, вона відповідає за Всесвіт, вона єдина, хто має розум, але в плані культурогенезу і біоценозу культури людина презентується певними кодами культурогенезу - теріоморфізмом, теоцентризмом, антропоцентризмом.

Отже, візуальний і семіотичний повороти $є$ певним епіцентром антропологічного повороту, який не можна відразу побачити, бо всі сприймають людину як константу культурогенезу. Антропоцентризм моди не $є$ всезагальним, у ній надзвичайно гостро абсолютизуються і завжди реактивізуються тваринні коди теріоморфізм. Якщо ідеться про циклізм культуротворення, що $є$ конституативною ознакою моди, то варто говорити про певну алгоритмізацію моди, визначення логістичних, семіотичних та антропологічних констант. Антропологізм моди $€$ медіальним та екзистенційним. «Теза про те, що все $є$ медіа, з необхідністю призводить до визначення медіа всередині нас, - пише В. Савчук (2013). - Вони направляють нашу аналітичну установку на відстеження тієї роботи, котру вони відтворюють всередині нас (конструкція сприйняття) і поза нами (відбір та селекція того, що сприймається). Кожний вид медіа $є$ акциденцією. Конкретний вид медіа створює свою реальність, свій спосіб практики поведінки з ним, адже також - і це завжди потрібно пам'ятати - він має своє окреслення/обмеження, обмежені засоби, що вкорінені в побудові тих апаратів і засобів, які ми використовуємо» (с. 39).

Циклізм моди як медіальний феномен задається генетично ідеацією, ритуальною циклічністю актів культурогенезу, що $є$ найважливішим конституативним механізмом культуротворення, за П. Сорокіним (1992). Отже, ми мусимо знайти певного «конструктора» моди, продуцента модного універсуму, що субстанційно визначається як модність, орієнтація на гру, сцену буття людини в цілому. Цей сценізм набуває розгорнутого антропологічного образу свого існування в Давній Греції. Це театрон як феномен культури - величезний простір видовищ, змагань, олімпіад. Театрон - це певний ланцюг єдності людини і світу. Втім людина не помічається, домінує імперський світ видовища космічного агону. Однак у XXI столітті «імперія людини», про яку писав А. Печчеї (Печчеи, 1985), за- 
сновник римського клубу, перетворюється на імперію планетарного людства. Різко змінюється й мода - ії цикли коливання фрормуються в межах від тотальної гомогенізації, уніфікації до локалізації етнокультурних спільнот.

Якщо ноосферний проект В. Вернадського (Вернадский, 2004) $є$ верхівкою модерну в широкому розумінні, то варто зазначити, що ноологія і взагалі неоплатонізм, на який орієнтувався Вернадський, не втратили свого регулятивного сенсу. Так, О. Лосєв (Лосев,1960) пише про неоплатонізм як примат духовності в широкому сенсі. Втім тут важко побачити християнський підтекст, який $€$ наявним у Тейяр де Шардена (2012). Все свідчить про те, що хронологічне рознесення антропологічного, семіотичного і візуального поворотів $€$ однією із герменевтичних схем XX століття, яку потрібно подолати і побачити в рамках тих конструкцій, які існують у плані культуротворення як реальність естетичного світу - в широкому сенсі чуттєвого розуміння. Це дає можливість побачити залежність всіх антропологічних імплікацій культуротворення від базових, більш широких предикацій, що пов'язані зі світовим розумом, космічним тілом у Давньої Греції і взагалі з алгоритмами моди: тілесністю, платоновими тілами, які пізніше описують у вигляді графематики, морфем, синтагматики, синтаксису як лінгвістичних конотацій семіозу в моді.

Важливо, знов-таки, звернутися до Середньовіччя, де теоцентризм презентує Абсолют у концентрованому, іконічно наявному вигляді. Це прекрасно описав П. Флоренський (1914), який зазначив, що божество утворюється на білому тлі, яке нагадує розмальований гіпс мумії, а тіло мерця автоматично перетворювалось на бога Озиріса. Втім ікона стає більш символічним, більш міфрологічно структурованим простором тілесних імплікацій із точки зору презентації Абсолюту. Ікона втрачає первинний теріоморфізм. Домінанта семіотичної складової як символічного, логічного цілого $є$, звичайно, тут пріоритетною, але не менш пріоритетним залишається антропологічна складова як образ Божий. Складова візуальна презентує наявність божества в іконі, намоленому образі, який фрактично вступає субститутом Абсолюту.

У візантійській культурі формується новий синкретизм, нова синтагматика, новий простір, який Л. Жегін (Жегин, 1970) та В. Фаворський (Фаворский, 1966) визначили таким чином: плоский рельєф культури Давньої Греції (розшарування цінностей) «вигинається» навколо центральної осі - теоцентричної вертикалі. Адже рельєф кам'яний не витримує напруги вигину (символічної напруги) і «тріскається», в тріщинах проривається безодня небуття.

\section{- Висновки}

Встановлено, що культура XX століття трансформує глибинні імплікації язичництва, християнства, іконізм, антропологію образу людини як єдність трансцендентного та профанного. Особливо це помітно в моді, всіх її сценах, де людина має справу завжди з земним буттям, а естезіс (чуттєві відносини до земного буття) завжди вимагає винесення на перший план не лише антропоморфнних, але й теоморфнних складових культуротворення. Мода виносить на поверхню ті імплікації модності, вічної ювенальності людини, що набувають візуальних фрорм молодого тіла, яке вже не має смертної фрорми існування. 
Кіборги (віртуальні істоти) трансформують антропологію моди в екранних формах трансформації буття, резонують простір, пов'язаний із давніми цивілізаціями. Культ фентезі, стиль грандж, кіберпанк у моді створюють новітній простір модних анклавів XXI століття. Абсолют усувається, він вже не потрібний, головне - його візуальна копія, яка є тотальним субститутом тієї реальності, що пов'язана з Абсолютом, але не є сакральною. Утворюється нова синкретична реальність моди, що поєднує теоморфізм, антропоморфізм та теріоморфізм.

Отже, мода стає гармонізуючим фрактором уніфікації та гомогенізації смаків завдяки ї̈ вкоріненості в найголовніші реалії культуротворення: антропологічний, предметно-символічний, семіотичний та вербальний коди комунікації. Автор вбачає подальшу перспективу антропологічного аналізу моди як синтетичну цілісність метакультурних, метахудожніх, мультисценічних синтез.

\section{- Список використаних джерел}

Барна, Н.В. (2015). Дизайн у контексті художньої культури XX-XXI століть [Монографія]. Київ: Університет "Україна".

Барт, Р. (2003). Система моды. Статьи по семиотике культуры (С.Н. Зенкина, Пер.). Москва: Издательство имени Сабашниковых.

Вернадский, В.И. (2004). Биосфрера и ноосфрера. Москва: Айри-Пресс.

Жегин, Л.Ф. (1970). Язык живописного произведения. Москва: Искусство.

Легенький, Ю.Г. (2003). Философрия моди XX столетия. Киев: Киевский национальный университет культуры и искусств.

Лосев, А.Ф. (1960). Предшественники неоплатонизма. В С.И. Соболевский, М.Е. ГрабарьПассек, \& Ф.А. Петровский (Ред.), История греческой литературы (Т. 3, с. 374379). Москва: Академия наук СССР.

Печчеи, А. (1985). Человеческие качества (О.В. Захарова, Пер.). Москва: Прогресс.

Пигулевский, В.О. (2015). Жанры массовой культуры и графиический дизайн. ВВ.О. Пигулевский, \& А.В. Овруцкий (Ред.). Визуальные коммуникации в рекламе и дизайне (с. 91-121) (2-е изд.). Харьков: Гуманитарный центр.

Савчук, В. (2013). Медиафрилософрия. Приступ реальности. Санкт-Петербург: Издательство РХГА.

Сорокин, П.А. (1992). Человек. Цивилизация. Общество. Москва: Политиздат.

Тейяр де Шарден, П. (2012). Феномен человека. Москва: АСТ.

Усманова, А. (2007, 6 октября). Визуальные исследования как исследовательская парадигма. Взято из https://web.archive.org/web/20071006101629/http://viscult.ehu. It/article. php?id=108.

Фаворский, В.А. (1966). О рисунке. О композиции. Фрунзе: Кыргызстан.

Флоренский, П.А. (1914). Столп и утверждение истины: опыт православной теодицеи в двенадиати письмах. Москва: Путь.

Шмить, Ф.И. (1919). Искусство: его психология, его стилистика, его эволюиия. Харьков: Книгоиздательство "Союз" Харьковскаго Кредитнаго Союза Кооперативовъ.

\section{- References}

Barna, N. (2015). Dyzain u konteksti khudozhnoi kultury XX-XXI stolit [Design in the context of the art culture of the $20^{\text {th }}-21^{\text {st }}$ centuries] [Monograph]. Kyiv: University of "Ukraine" [in Ukrainian]. 
Barthes, R. (2003). Sistema mody. Stati po semiotike kultury [Fashion system. Articles on the semiotics of culture] (S.N. Zenkina, Trans.). Moscow: Izdatelstvo imeni Sabashnikovykh [in Russian].

Favorskii, V.A. (1966). O risunke. O kompozitcii [On drawing. On composition]. Frunze: Kyrgyzstan [in Russian].

Florenskii, P.A. (1914). Stolp i utverzhdenie istiny: opyt pravoslavnoi teoditcei $v$ dvenadtcati pismakh [The pillar and affirmation of truth: the experience of the Orthodox theodicy in twelve letters]. Moscow: Put [in Russian].

Legenkii, lu.G. (2003). Filosofiia modi XX stoletiia [The philosophy of fashion of the twentieth century]. Kyiv: Kyiv National University of Culture and Arts.

Losev, A.F. (1960). Predshestvenniki neoplatonizma [Predecessors of neoplatonism]. In S.I. Sobolevskii, M.E. Grabar-Passek, \& F.A. Petrovskii (Eds.), Istoriia grecheskoi literatury [History of Greek Literature] (Vol. 3, pp. 374-379). Moscow: Akademiia nauk SSSR [in Russian].

Peccei, A. (1985). Chelovecheskie kachestva [Human qualities] (O.V. Zakharova, Trans.). Moscow: Progress [in Russian].

Pigulevskii, V.O. (2015). Zhanry massovoi kultury i graficheskii dizain [Genres of Mass Culture and Graphic Design]. In V.O. Pigulevskii, \& A.V. Ovrutckii (Eds.). Vizualnye kommunikatcii v reklame $i$ dizaine [Visual Communications in Advertising and Design] (pp. 91-121) (2nd ed.). Kharkov: Gumanitarnyi tcentr [in Russian].

Savchuk, V. (2013). Mediafilosofiia. Pristup realnosti [Media Philosophy. Reality's attack]. St. Petersburg: Izdatelstvo RKhGA [in Russian].

Shmit, F.I. (1919). Iskusstvo: ego psikhologiia, ego stilistika, ego evoliutciia [Art: its psychology, its stylistics, its evolution]. Kharkov: Knigoizdatelstvo "Soiuz" Kharkovskago Kreditnago Soiuza Kooperativov [in Russian].

Sorokin, P.A. (1992). Chelovek. Tcivilizatciia. Obshchestvo [Man. Civilization. Society]. Moscow: Politizdat [in Russian].

Teilhard de Chardin, P. (2012). Fenomen cheloveka [Human phenomenon]. Moscow: AST [in Russian].

Usmanova, A. (2007, October 6). Vizualnye issledovaniia kak issledovatelskaia paradigma [Visual research as a research paradigm]. Retrieved from https://web.archive.org/ web/20071006101629/http://viscult.ehu.It/article.php?id=108 [in Russian].

Vernadskii, V.I. (2004). Biosfera i noosfera [Biosphere and noosphere]. Moscow: Airi-Press [in Russian].

Zhegin, L.F. (1970). lazyk zhivopisnogo proizvedeniia [The language of the painting]. Moscow: Iskusstvo [in Russian]. 


\title{
- ANTHROPOLOGICAL TURN AS REFLECTION PHENOMENON IN THE FASHION OF THE $20^{\text {th }}-21^{\text {st }}$ CENTURIES
}

\author{
- Nataliia Barna \\ Doctor of Philosophy, Professor, \\ ORCID: 0000-0002-5176-0136, e-mail: barna2005@ukr.net, \\ Open International University of Human Development "Ukraine", \\ Kyiv, Ukraine
}

\section{Abstract}

The purpose of the article is to determine the socio-cultural determinants of the systems building of fashion activity interpretation as a factor of harmonization of global problems of the times. The research methodology has used comparative and systematic approaches to help to define fashion as a system of changes and innovations in the context of anthropological issues. Philosophical methods such as the transcendental help to clarify how changes in fashion innovation in the age of globalization are possible; how the changes themselves (the phenomenological method) become obvious; as one cycle of fashion innovation transforms into another. The method of cultural and historical reconstruction helps to identify fashion artefacts as a phenomenon of modern culture. Scientific novelty. The anthropological turn focuses on the anthropic dimension of fashion, which testifies to the anthropological dependence of motive theocentricism and zoomorphism. Conclusions. It is proved that in the theory of modern aesthetic thought, art, cultural studies determine three turns: anthropological, semiotic and visual. As it happens, these turns are bred in time and it is believed that the anthropological come before the semiotic. The issues of discourse, text, sign transform the man's problem, which was sharply marked at the turn of the $19^{\text {th }}-20^{\text {th }}$ centuries, into the plane of linguistic adequacy. The anthropological turn reflects the present situation, which presents the excessive, more, extremely extravagant reality of the visualization of the world, a new optics, a panoptic universe that enables the media, advertising, virtual reality to show, present, expand the world of information so much so man is in the multivariate space of the multidimensional screen world. The screen becomes so active and active that it actually eliminates physical and identity problems as an ontological predicate. The ontological transformations in the fashion of the twentieth century are defined in the context of this article through the prism of cultural practices of the present day.

Keywords: culture; fashion; anthropological turn; semiotics; visual world of fashion 


\section{- АНТРОПОЛОГИЧЕСКИЙ ПОВОРОТ КАК ФЕНОМЕН РЕФЛЕКСИИ В МОДЕ XX-XXI ВЕКОВ}

\section{- Барная Наталья Витальевна}

- Доктор фрилософрских наук, профрессор,

ORCID: 0000-0002-5176-0136, e-mail: barna2005@ukr.net,

Открытый международный университет развития человека «Украина», Киев, Украина

\section{Аннотация}

Цель статьи - определить социокультурные детерминанты формирования систем интерпретации модной деятельности как фактора гармонизации глобализационных проблем современности. В исследовании использованы компаративный и системный подходы, что помогло определить моду как систему изменений и инноваций в контексте антропологической проблематики. Такие фрилософские методы, как трансцендентальный, помогают выяснить, насколько возможны изменения модных инноваций в эпоху глобализации; каким образом становятся явными сами изменения (феноменологический метод); как один цикл модных инноваций превращается в другой. Метод культурноисторической реконструкции помогает определить модные артефакты как феномен новой культуры, нового модного цикла. Научная новизна. Антропологический поворот концентрирует внимание на антропном измерении моды, свидетельствующем об антропологической обусловленности теоцентризма и териоморфизма. Выводы. Доказано, что в теории современной эстетической мысли, искусствоведении, культурологии определяют три поворота: антропологический, семиотический и визуальный. Так случилось, что эти повороты разводят во времени, и считается, что антропологический предшествовал семиотическому. Проблема дискурса, текста, знака трансформирует проблему человека, которая была остро обозначена на рубеже XIX-XX веков, в плоскость речевых адекваций. Антропологический поворот отображает сегодняшнюю ситуацию, представляющую чрезмерную, более того, очень экстравагантную реальность визуализации мира, новый оптикум, паноптический универсум, дающий возможность массмедиа, рекламе, виртуальной реальности демонстрировать, представлять, расширять мир информации настолько, что человек почти постоянно находится в поливариантном пространстве многомерного мира экрана. Экран становится настолько действенным и активным, фрактически устраняет проблемы телесности и идентичности как онтологического предиката. В контексте статьи определяются онтологические трансформации в моде XX века через призму культурных практик современности.

Ключевые слова: культура; мода; антропологический поворот; семиотика; визуальный мир моды 